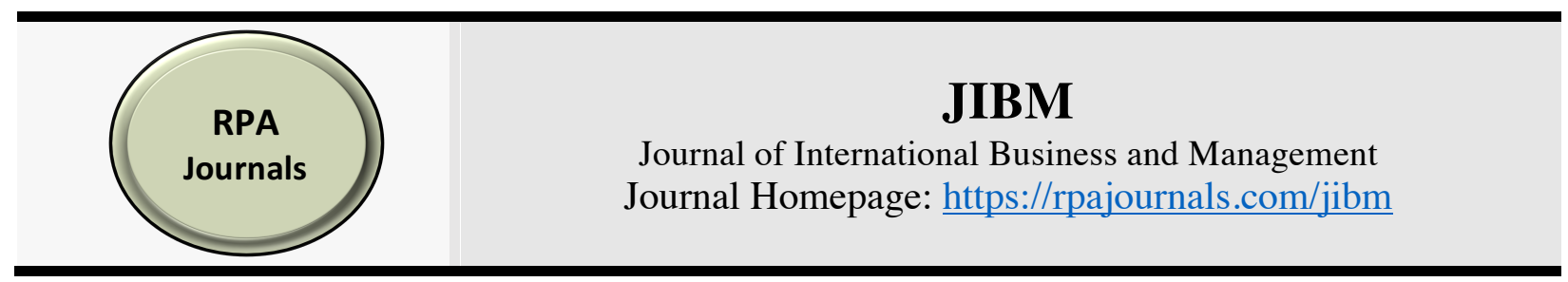

\title{
Effect of Organisational Culture on Sustainable Growth of SMEs: Mediating Role of Innovation Competitive Advantage
}

\author{
Danjuma Tali Nimfa ${ }^{{ }^{*}}$ \\ Ahmad Shaharudin Abdul Latiff ${ }^{2}$ \\ Sazali Abdul Wahab ${ }^{3}$ \\ Patrick Etheraj ${ }^{4}$ \\ Putra Business School (PBS) $)^{1,2,3,4}$ \\ Universiti Putra Malaysia (UPM), Malaysia ${ }^{1,2,3,4}$
}

\begin{abstract}
The purpose of this study is to investigates the effect of organisational culture on the sustainable growth of SMEs; mediating role of innovation competitive advantage. The electrical products small and medium enterprises was the realm of this study. The partial least squares structural equation modelling (PLS-SEM) via SmartPLS was employed to test the hypotheses. Finding of this study revealed that organisational culture has a direct positive significant effect on sustainable growth of SMEs and innovation competitive advantage. Moreover, the study confirmed that innovation competitive advantage has a direct positive significant relationship with sustainable growth of SMEs. Furthermore, the findings established that innovation competitive advantage has fully mediates the relationship between organisational culture and sustainable growth of electrical manufacturing SMEs in Nigeria. This study sets out purposeful measures to encourage owner-mangers of the electrical manufacturing SMEs to maintain as well as installing innovative organisational culture that enhance efficient sustainable growth of SMEs and embedding innovation competitive advantage as a viable strategic mechanism in the enterprise. This study is distinctive because it tries to fill the small and medium enterprises gaps through encouraging managers of the electrical manufacturing SMEs to always strategize for better sustainable growth in the rapidly changing business environment.
\end{abstract}

Keywords: Organisational culture, Sustainable growth of SMEs, Innovation competitive advantage, PLS-SEM (SmartPLS)

*Corresponding author: Danjuma Tali Nimfa; Email: nimfad@unijos.edu.ng

DOI: $\underline{\text { https://doi.org/10.37227/JIBM-2021-01-156 }}$

\section{Introduction}

Sustainable enterprises prioritise and apply environmental principles and socially responsible behaviour in all business decisions and incorporate it into their business strategy (Gross-Gołacka, Kusterka-Jefmańska, \& Jefmański, 2020). Globally, small- and medium-sized enterprises (SMEs) play a key role in driving sustainable economic growth in both developed and developing countries (Diabate, Allate, Wei, \& Yu, 2019a; Nimfa et al., 2019). The impact of sustainable growth of SMEs 
in a particular economy depend on effective organisational culture. The enterprises must place it economic, social and environmental strategy around the societal norms and values where it operates for sustainable growth and development (Nimfa, \& Gajere, 2017). Nonetheless, researches have observed that sustainable growth contexts has been established largely in advanced economy perspectives as relates to addressing the multinational enterprises. While sustainable growth in small and medium enterprises (SMEs) had witnessed obvious challenges regarding employing desired strategies. Small and medium enterprises recognised that organisational culture structure is directly or indirectly difficult and considered it not easily realisable strategy in the current business environment. Several previous research attempted to recognise the effect of organizational culture adoption and certain procedures but this have not properly fit into the sustainable growth of SMEs plan to drive their affairs to enviable high.

Organisational culture is indeed a conceptual instrument capable of providing further useful ideas about the fallacy (Taylor, 2014). Organisational culture is a system of common principles, assumptions and ideologies on to create capabilities and strategies, sustain work life as well as great culture that impacted the business innovation and performance (Barney, 1986; Hofstede, 1990; Schein, 1990; Santti et al., 2017). Similarly, organizational culture may not significantly impact on small-firm efficiency, but would influence strategy-making processes through the company's entrepreneurial orientation of the company and in essence, could shape performance of the firm (Hynes, 2009; Khedhaouria et al., 2020). According to (Asare, 2014; Yoo et al., 2018) the key problems facing small and medium enterprises are scarcity of access to credit facilities, insufficient infrastructure, inadequate research and development capacity, competitiveness and insufficient knowledge/skills for the management.

The current research focused on manufacturing SMEs in Nigeria in the context of organisational culture and sustainable growth of electrical product manufacturing SMEs. This research would evaluates owner managers' alertness to understanding of perspectives on the effect of organisational culture and sustainable growth of electrical manufacturing SMEs. The study would predict the importance of enterprise components in structuring the sustainable growth of the SMEs. Previous research focused on the sustainable development and firm performance but in Nigeria less attention was given to the context of sustainable growth of manufacturing SMEs specifically in relative to electrical product enterprises. Accordingly, recent work of scholars has observed that presently there is no all-inclusive set of operations central to the effect organisational culture and sustainable growth of manufacturing SMEs and empirical research is scarce in Nigeria. Based on the above discussion in this research, the central aim of this study was to develop a strategic initiative model through the proposed conceptual research framework of organisational culture and sustainable growth of manufacturing SMEs. The model that describes all-encompasses constructs in the study's framework and items that are important to the operation and contextual viewpoints of SMEs. In view of that, two research questions pushes the struggles ahead of this research: "To what extent has organizational culture encourage sustainable growth of electrical product manufacturing SMEs?" "To what extent has innovation competitive advantage mediates the effect of organisational culture on the sustainable growth of electrical product manufacturing SMEs?"

The research objectives of this study are to pragmatically analyse the effect of organisational culture on sustainable growth of electrical product manufacturing SMEs in Nigeria; to investigate how innovation competitive advantage mediates the effect of organisational culture on sustainable growth of electrical product manufacturing in Nigeria. Subsequent parts of this research focused on literature regarding, sustainable growth of SMEs (SGSMEs), Innovation competitive advantage (ICA) and organisational culture (OC), the relationships between organisational culture and sustainable growth of SMEs, the mediating effect of innovation competitive advantage between organisational culture and sustainable growth of SMEs would be reviewed and the conceptual framework was proposed. This part was followed along with the research method employed, results and discussion of findings, conclusions, limitations of the study as well as direction for future research 


\section{Literature Review}

\section{Sustainable Growth of SMEs (SGSMEs)}

Sustainable growth of SMEs is self-sufficiency growth by achieving financial objectives and performance that is continuous over time and within the firm's capabilities while affirming and sustaining future objectives without jeopardising its long-term survival (Yusoff et al., 2018). Growth in any form is virtually treated as an optimum unique component of firms' performance (Arora, Kumar, \& Thapar, 2018). The concept of sustainable growth requires enterprises to search for and implement methods and tools of management, which allow for the inclusion and integration of not only economic, but also social and environmental development goals (Gross-Gołacka et al., 2020; Diabate et al., 2019a). Sustainable growth another significant concept that was traced back to (Babcock, 1970) has remained crucial in assisting managers to make enormous financial choices for the enterprises (Arora et al., 2018). Evidence from past scholar's work has suggested that a sustainable entrepreneurial activities encouraged leaders and owner-managers to oversee their operational process by aligning financial decisions, environment and social goals to offer a distinctive triple bottom line (Nor-Aishah et al., 2020; . Abdul-Rashid et al., 2017; Hami et al., 2016).

\section{Organisational Culture (OC)}

Organisational culture is the degree to which managers' values are "inherent in the core organisational values, which is often unconscious and rarely discussable" (Hofstede, 1990; Tang et al., 2000). Organizational culture embodies shared of values or beliefs about employee acceptability and behavioral standards to address organizational challenges (Gorondutse, \& Hilman, 2019; Adebayo, 2011; Daft, 2005; Goffee, \& Jones, 1998). Organizational culture has been seen as collecting the behaviours, attitudes, values, assumptions or beliefs of members within a group (Gorondutse, \& Hilman, 2015).Thus, organizational culture has been grouped into three categories such as supportive, innovative and bureaucratic, which is perceived to be the core of informal perceptions with a distinctive state of mind that would encourage the employees' behaviour, actions and attitudes (Gorondutse, \& Hilman, 2015; Ahmad et al., 2011; Wallach, 1983). Abdul-Halim, Ahmad, Geare and Thurasamy, (2018) maintained that more effort is needed to understand the concept of innovation cultures between small and medium enterprises taking into account the context of less developed countries. Additionally, clan culture implies that environmental activities could be managed by taking care of customers as collaborators and empowering employee loyalty via team cohesion and opportunities for staff developmental (Dzomonda, \& Fatoki, 2019; Cameron, \& Quinn, 2006). Small and medium enterprises strive to develop new products that deliver innovation results by incorporating innovative culture of crowdsourcing from the ideology of the social communities as demonstrated by suppliers and consumers (Srisathan et al., 2020). Furthermore, owner-managers wishing to pursue more immateriality and sustainable business operation should aspire preserve the culture and social well-being of long-term workers through a sound association between geographic ethical identities (Kraus et al., 2020).

\section{Innovation competitive advantage (ICA)}

Innovation competitive advantage can be described as a capability for an enterprises which is productive that creates new competitive advantage through perceived and discovery of new and better approach to competes within an enterprise and introduce it to the marketplace (Sheng et al., 2013; Porter, 1990; Whalen \& Han, 2017; Nimfa, Latiff, \& Wahab, 2020). In addition, one of the characteristics of success is contingent on the advantage of innovation (Angelmar, 1990). Also, innovation competitive advantage can be defined as the level at which management think through central increase and attainable or profitable results, via the research and development, sound resource management and value addition capacity, product/service innovation uniqueness for sustainable growth of the business (Sheng et al., 2013; Paswan, \& Wittmann, 2009; Dirsehan, 2015; Conto et al., 
2016). Innovation help in creating sustainable growth leading to competitive advantages internally or externally in the marketplace (Distanont, \& Khongmalai, 2018; Teece, Pisano, \& Shuen, 1997).

Likewise, (Teece et al., 1997) suggests that private wealth creation in regimes of rapid technological change depends in large measure on honing internal technological, organizational, and managerial processes inside the firm. Previous researches has showed that innovation is a key driver of sustained competitive advantage and sustainable business growth, the management of innovation is a central concern for these firms (Whalen \& Han, 2017; Igartua et al., 2010; Goksoy et al., 2013). According to (Distanont, \& Khongmalai, 2018) 'the role of innovation is an important key that leads to the creation of competitive advantages for businesses, and therefore SMEs such as the frozen food industry must pay attention to creating innovation, in particular external skills, knowledge, and experiences that can foster innovation and create competitive advantage for SMEs'. In relation, and to address unfortunate circumstances that would assist in attaining sustainable growth, SMEs and larger firms must prepare some long-term growth strategies to enhance their capacity for innovation (Yoo et al., 2018).

\section{Organisational Culture and Sustainable Growth of SMEs}

Diabate et al. (2019b) confirmed that there is a singnificant relationship between small and mediumsized enterprises sustainable growth (SMESG) and each entrepreneurial ability (EA) dimension such as creativity, risk control, relationship and/or opportunity detection ability) and learning ability accepted. In a similar vein, (Al Badi, 2019) has found that organizational culture was related to the whole society's culture, which has changed over recent years due to changes in lifestyle and consumer behaviour in (Srisathan et al., 2020) reported that there was a significant effect of organizational culture on organizational sustainability in that cultural characteristics maintain the core business competencies in terms of marketing, operations, customer orientation, capital management, and monitoring \& evaluation for sustainability (Mohammed et al., 2020). Clearly, this is not to overlook the fact that sustainability may also be linked to issues of, for instance, durability or continuity; nevertheless, increasing particular attention is required in relation to (environmental) sustainability especially in small-to-medium-sized enterprises [SMEs] (Kraus et al., 2020, Spence, 2016; Wickert et al., 2016). Likewise, (Gorondutse, \& Hilman, 2019) have established that there was a strong positive impact of organizational culture on the performance of the small-scale industries. However, (Dzomonda, \& Fatoki, 2019) found that small and medium enterprises (SMEs) had an average level of entrepreneurial orientation (EO) as well an average level of organisational culture. In like terms, using multiple-responding data from the cross-sectional enterprise dataset and a rigorous measurement of sustainability-related performance innovation, empirical findings revealed that clan culture had a negative effect on sustainability-related innovation performance, while hierarchical and adhocracy cultures have positive effects (Globocnik et al., 2020). Peteraf, 1993; Ćelić, et al., 2019) "Identified differences in the consequences of certain cultural dimensions on the observed performances of SMEs in Serbia, point to the need to create specific strategies for the development of organizational culture for these two SME segments in Serbia (CIOs, KIOs)". Therefore, based on the assertions mentioned above the relationship between organizational culture and sustainable growth of SMEs has inconclusive findings. Thus, we hypothesised that:

$\mathrm{H}_{1}$ : There is a significant association between organisational culture and sustainable growth of SMEs. $\mathrm{H}_{2}$ : There is a significant association between organisational culture and innovation competitive advantage.

$\mathrm{H}_{3}$ : There is a significant association between innovation competitive advantage and sustainable growth of SMEs

\section{Innovation competitive advantage as Mediating Variable}

Amplified uncertainty in the business environment recently has been adding more hard times of improving performance and securing a competitive advantage for sustainable growth (Goksoy et al., 2013]. Evidence from previous researches by (Anwar et al., 2018) reported that competitive advantage totally mediates the connection amid intellectual capital and performance of new venture, 
related, competitive advantage partially mediates the relation between entrepreneurs' strategy and new ventures. Likewise, competitive advantage partly mediated between the political networks and new enterprise (Anwar et al., 2018). Zhang, Wang and Song (2020) suggested that increased competitive strength decreases and does not increase the positive influence of market capabilities, in performance, therefore, when competitive intensity become high, the positive effects of market capabilities on performance become very insignificant. Competitive advantage mediated partially the relationship between business model innovation (BMI) and small and medium enterprise (SME) performance (Anwar, 2018). Accordingly, Anwar, Rehman and Shah (2018) advanced that competitive advantage has strongly mediated the relationship between financial network and new venture performance, business networking and new venture performance. "Firms in these mature markets must look for ways to stay competitive and develop strategies that enable them to differentiate themselves from other firms" (Rua et al., 2018). Recent, enterprises have been forced to use unconventional control strategies and approaches because of rapidly growing competitiveness of the market environment. 'Maintaining competitive advantage is a dynamic and infinite activity' (Hung, Yang, \& Lien, 2010; Rua et al., 2018). Business managers must look inward to allow the achievement of the desired results to meet customer needs and enabling to engage in sound capability of innovation competitive advantage. This ensures that the enterprises are in conjunction with the Jet edge period that would assist them in organisational culture reengineering and reorientation for sustainable growth of the SMEs. The assertions discussed above indicated that most research focused on using competitive advantage as a mediator variable, while less attention was paid to the innovation competitive advantage. Therefore, this current study has chosen to contribute to the existing knowledge and literature gap in strategic management by introducing the role of innovation competitive advantage to mediate the relationships between organisational culture and sustainable growth of manufacturing SMEs. Thus, the study hypothesised that:

$\mathrm{H}_{4}$ : Innovation competitive advantage mediates the relationship between organisational culture and sustainable growth of SMEs.

\section{Research Framework}

This research novelty is the investigation of the connections between organisational culture (OC) and sustainable growth of small and medium enterprises being mediated by innovation competitive advantage that was established on the research framework as presented in Figure 1.

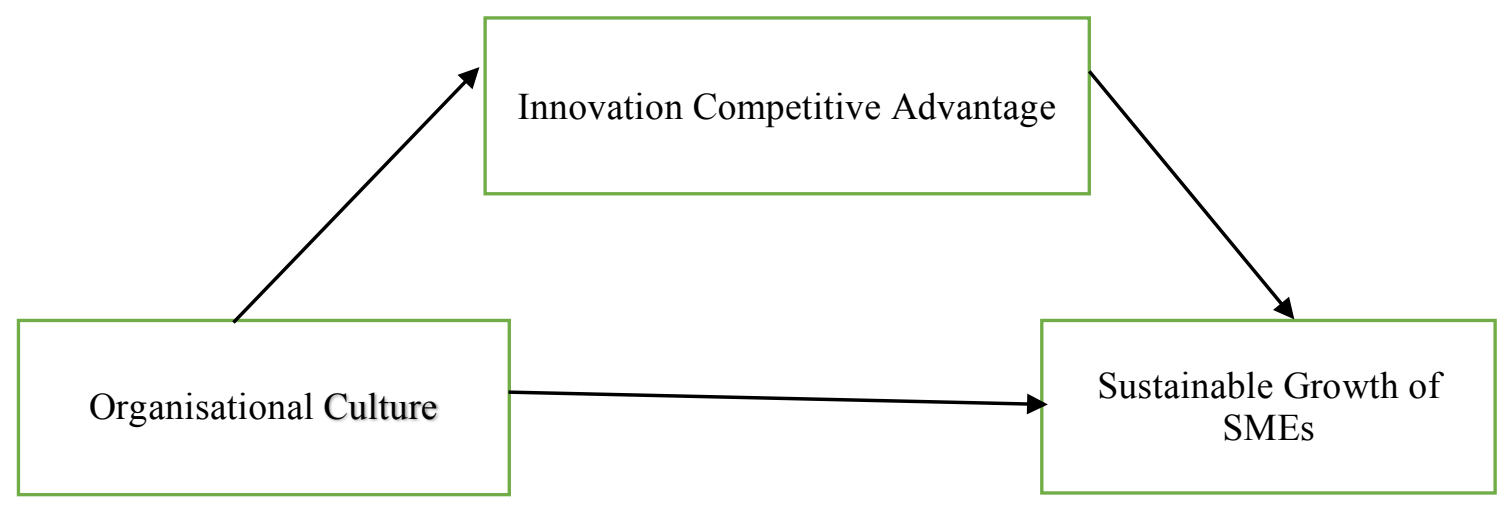

Figure 1: Research Framework on Organisational Culture (OC) and Sustainable Growth of SMEs (SGSMEs.

\section{Survey and Data Collection}

\section{Research Methods}

In Nigeria, small and medium enterprises (SMEs) within the manufacturing enterprises can be described as the organisations with an assets based of that is less than 500,000,000 million naira or a 
number of employees hired that is not more than 199 (Hung, Yang, \& Lien, 2010). The convenient sampling method was adopted for selecting the participants based on the identified criteria as follows: it must be an electrical product manufacturing SMEs; it has to be an enterprises that has from 5 and not more than 199 employees, assets based is 5,000,000 million naira and less than 500,000 million naira; and business location was between Abuja - Federal Capital Territory (FCT) and Nasarawa state in the North Central Geopolitical Zones of Nigeria. The two state were chosen in this research because the composition of electrical product manufacturing small and medium enterprises (SMEs) are significant in these two locations. The bulk of these SMEs are situated in Abuja- FCT (21.12\%) and Nasarawa state only represented (19.46\%) mainly in the North Central geopolitical Zone of Nigeria (NBS/SMEDAN, 2017). The target respondents are the owner-managers/founders, who are still sustaining to manage their enterprises. This study exempted the micro enterprises category because they had less than 10 employees and assets based was less than 5,000, 000 million naira (Mekwunye, 2018). This is due to their inadequate infrastructural facilities and technology to promote sustainability practice of the enterprise (Akinson, 2018; Buowari, 2015].

From the 5429 registered SMEs with the Small and Medium Enterprise Agency of Nigeria (SMEDAN) in the directory records 2017, the small and medium enterprises that fulfilled the accepted sample frame requirements were 850 SMEs. The collected data took up to three months from November 2019 to February, 2020. The study used simple random sample method, through Google Forms linked to their mail 850 enterprises were sent the survey questionnaire to complete.

The enterprises were contacted through personal emails and phone calls in case of bounced, spam mails and to also check the valid mails. To enable the obtaining of quick response, a follow-up call with reminder notes was send after two weeks, one and half month and two and half months respectively. The total of 247 enterprises were collected after the third month having 29.06 percent response rate. The response rate is low when conducting any organisational research dealing with owner managers usually close to 20 percent would be considered optimistic (Saleh, \& Ndubisi, 2006; Nimfa et al., 2020), which is equivalent to similar research in developing countries, especially Nigeria. This was consistent with the study of (Sekaran, \& Bougie, 2016), they stated that the ideal response rates in social sciences researches are 5 percent and 35 percent accordingly. Hence, based on $G$ Power calculation analysis, the date collected as sample size was adequate. Using the recommended minimum sample size was 68 using two predictor for the conceptual framework and applying the effect size 0.15, alpha 0.05 and statistical power 80\% (0.80) (Cohen, 1992; Hair, Bush, $\&$ Ortinau, 2006). Furthermore, 247 sample collected was more than the minimum sample required for this study and sufficient representative of the population in this research.

\section{Measurements}

The measurement for sustainable growth of small and medium enterprises (SGSMEs) was adopted from [Arora et al., 2018, Eggers et al., 2013a; Eggers et al, 2013b; Al-Ansari 2014) with the alpha value 0.89 which consists of 5 selected items as follows: "we achieved customer satisfaction for sustainable growth, we achieved higher growth in employees than our direct/indirect competitors, we achieved higher profit growth than our direct/indirect competitors, we achieved higher sales growth than our direct/indirect competitors and we achieved higher growth in market share than our direct/indirect competitors". The measurement of organisational culture (OC) was adopted from (Tang et al., 2000) with the alpha value 0.92 which contains 5 selected items for measures include: "Our company tries to create a unique family atmosphere, our manager/supervisor encourages people to speak up when they disagree with a decision, our enterprise give employees the opportunity to meet with their managers one-to-one at least twice a year to discuss growth performance and goals, our enterprise often communicates the overall organisational target goals and our enterprise's ethical code is the guidance of common behaviour". Meanwhile, the measurement for innovation competitive advantage (ICA) comprises of 5 selected items such as, "our enterprise is more capable of R\&D than our competitors, our enterprise has better managerial capability than our competitors, our enterprise profitability is better than our competitors, our enterprise take the market innovation competitive advantage better than competitors do and our enterprise's corporate image is better than that of the competitors" adopted from (Sheng et al., 2013; Chen et al 2009; Paswan, \& Wittmann, 
2009; Nimfa et al., 2020) with alpha value 0.947. All constructs used 5-point Likert scale ranging from 1 strongly disagree to 5 strongly agree were adopted for answering each item of the unidimensional constructs.

\section{Result and Discussion of Findings}

\section{Demographic Results}

From the total of 247 respondents, $57.1 \%$ are male whereas $42.9 \%$ are female. Mostly they are between 41 to 50 years old (27.5\%), followed by 51 and above years old $(25.1 \%)$, while 31 to 40 years old $(24.7 \%)$, and 21 to 30 years old $(22.7 \%)$. Most of the respondents has professional certificate./training (30.8\%), followed by diploma holders (19.4\%), SSCE with (17.8\%), BSC/HND (15.8\%), MSc (7.7\%), FSLS (6.5\%) and PhD (2.0\%). Owner managers or Founders $(42.1 \%)$, Director General or Unit Heads (26.3\%), Supervisors or Managers (17.0\%) and Chief Executive or Managing Directors (14.6\%). The majority of manufacturing were small enterprises $(56.7 \%)$ with 10 to 49 employees hired, and $43.3 \%$ were from medium enterprises with 50 - 199 employees hired. Regarding the category of business or legal units, most of the electrical products manufacturing enterprises were from the limited liability $22.7 \%$ ), followed by partnership (16.6\%), private shareholding $(13.4 \%)$, joint venture $(6.9 \%)$ and franchise $(6.9 \%)$ respectively. In terms of assets based, $62.3 \%$ were small enterprises with 5, 000, 000 million naira to less than 50, 000,000 million naira, followed by $37.7 \%$ medium enterprises with 50,000, 000 million Naira to less than 500, 000, 000 million naira. Most of the electrical product manufacturing small and medium enterprises (SMEs) had experience for more than 11-15 years (30.0\%), followed by 6 to 10 years $(26.3 \%), 16$ to 20 years $(25.5 \%), 21$ years and above $(15.0 \%)$, and $1-5$ years has only (3.2\%). Meanwhile, Abuja has majority of SMEs with $(57.1 \%)$ and Nasarawa State with (42.9 \%) SMEs. The demographic information is presented in Table 2 as follows in the next page: 
Table 2 Demographic Information

\begin{tabular}{|c|c|c|c|}
\hline Items & Description & Frequency & Percentage (\%) \\
\hline \multirow[t]{3}{*}{ Gender } & Male & 141 & 57.1 \\
\hline & Female & 106 & 42.9 \\
\hline & Total & 247 & 100 \\
\hline \multirow[t]{5}{*}{ Age } & $21-30$ & 56 & 22.7 \\
\hline & $31-40$ & 61 & 24.7 \\
\hline & $41-50$ & 68 & 27.5 \\
\hline & 51 and above & 62 & 25.1 \\
\hline & Total & 100 & 100 \\
\hline \multicolumn{4}{|l|}{ Qualification } \\
\hline & FSLC & 16 & 6.5 \\
\hline & SSCE & 44 & 17.8 \\
\hline & Prof. Cert./Training & 76 & 30.8 \\
\hline & Diploma & 48 & 19.4 \\
\hline & $\mathrm{BSC} / \mathrm{HND}$ & 39 & 15.8 \\
\hline & MSC & 19 & 7.7 \\
\hline & $\mathrm{PhD}$ & 5 & 2.0 \\
\hline & Total & 100 & 100 \\
\hline \multicolumn{4}{|l|}{ Responsibility } \\
\hline & Supervisor/Mgr. & 42 & 17.0 \\
\hline & DG/Unit Heads & 65 & 26.3 \\
\hline & Founder/Owner Mgr. & 104 & 42.1 \\
\hline & $\mathrm{CEO} / \mathrm{MD}$ & 36 & 14.6 \\
\hline & Total & 247 & 100 \\
\hline \multicolumn{4}{|l|}{$\begin{array}{l}\text { Number. of } \\
\text { Employees Hired }\end{array}$} \\
\hline & $10-49$ & 140 & 56.7 \\
\hline & $50-199$ & 107 & 43.3 \\
\hline & Total & 247 & 100 \\
\hline \multirow{7}{*}{$\begin{array}{l}\text { Business Unit/Legal } \\
\text { Unit }\end{array}$} & Sole Proprietorship & 83 & 33.6 \\
\hline & Partnership & 41 & 16.6 \\
\hline & Limited Liability & 56 & 22.7 \\
\hline & Private shareholding & 33 & 13.4 \\
\hline & Joint venture & 17 & 6.9 \\
\hline & Franchise & 17 & 6.9 \\
\hline & Total & 247 & 100 \\
\hline \multicolumn{4}{|l|}{ Asset Base } \\
\hline & $5 \mathrm{~m}$-less than $50 \mathrm{~m}$ & 154 & 62.3 \\
\hline & $50 \mathrm{~m}$-less than $500 \mathrm{~m}$ & 93 & 37.7 \\
\hline & Total & 247 & 100 \\
\hline \multicolumn{4}{|l|}{ Years of Experience } \\
\hline & $1-5 y r s$ & 8 & 3.2 \\
\hline & $6-10 y r s$ & 65 & 26.3 \\
\hline & $11-15 \mathrm{yrs}$ & 74 & 30.0 \\
\hline & $16-20 \mathrm{yrs}$ & 63 & 25.5 \\
\hline \multirow{5}{*}{ Location } & 21 and above & 37 & 15.0 \\
\hline & Total & 247 & 100 \\
\hline & Abuja- FCT & 141 & 57.1 \\
\hline & Nasarawa State & 106 & 42.9 \\
\hline & Total & 247 & 100 \\
\hline
\end{tabular}




\section{Common Method Variance (CMV)}

The data collected in this study were retrieved through self-reports questionnaire, specifically from a particular source, because there is a risk of developing statistical and method biases from the usual scale properties (Podsakoff et al., 2003). A full collinearity testing is one approaches used in detecting a problem. Two or more variables are perceived to be collinear when they are measuring objects or constructs with the same criterion (Kock, \& Lynn, 2012). The Harman's single-factor test was utilised in this study, recommended by (Podsakoff, \& Organ, 1986; Bell, 2019), to analyse the data for common method variance (CMV). The principal component factor analysis results shows a maximum value of the single factor explained as $32.50 \%$ of the total variance presented in Table 3 , which was less than the threshold of 50\% (Conway, \& Lance, 2010; Brannick et al., 2010; Hair et al., 2014; Doty, \& Astakhova, 2020). Therefore, the total variance explained was below the threshold parameter, which has indicated that common method variance (CMV) was not a major issue that would likely cause any harm to the study's findings. The total variance explained is shown in Table 3 .

Table 3 Total Variance Explained

\begin{tabular}{ccccccc}
\hline & \multicolumn{5}{c}{ Initial Eigenvalues } & \multicolumn{3}{c}{ Extraction Sums of Squared Loadings } \\
Factor & Total & \% of Variance & Cumulative \% & Total & \% of Variance & Cumulative \% \\
\hline 1 & 4.875 & 32.500 & 32.500 & 4.875 & 32.500 & 32.500 \\
2 & 2.268 & 15.121 & 47.621 & 2.268 & 15.121 & 47.621 \\
3 & 1.794 & 11.963 & 59.584 & 1.794 & 11.963 & 59.584 \\
4 & .908 & 6.056 & 65.640 & & & \\
5 & .770 & 5.132 & 70.772 & & \\
6 & .745 & 4.970 & 75.742 & & \\
7 & .667 & 4.447 & 80.189 & & \\
8 & .628 & 4.185 & 84.374 & & \\
9 & .591 & 3.938 & 88.312 & & \\
10 & .546 & 3.638 & 91.950 & & & \\
11 & .460 & 3.068 & 95.017 & & & \\
12 & .433 & 2.886 & 97.904 & & & \\
13 & .301 & 2.009 & 99.913 & & & \\
\hline
\end{tabular}

Extraction Method: Principal Component Analysis.

\section{Results and Discussion of Findings}

To perform PLS-SEM analysis, the measurement model was first assessed to ensure the validity and reliability of the study model. This included analyses of composite reliability, convergent validity, and discriminant validity. The measurement model is illustrated in Figure 2.

Reliability was measured using Cronbach's alpha and composite reliability (CR), which should be above 0.7 and 0.8 , respectively (Hair et al., 2014). Meanwhile, convergent validity was measured based on average variance extracted (AVE) values, which should be above 0.5 (Hair et al., 2019). As shown in Table 4, all the constructs in the study met these criteria and thus displayed satisfactory reliability and convergent validity. Next, discriminant validity for the model was assessed using the heterotrait-monotrait (HTMT) ratio of correlations, which should be less than 0.85 (Voorhees et al., 2016) Based on Table 5, the study constructs met the discriminant validity criteria as well. Finally, the study model was tested for multicollinearity based on the items' variance inflation factor (VIF). Table 6 indicates that all items had VIF values below 3.33, which proves the non-existence of multicollinearity issues in this study (Hair et al., 2018; Voorhees et al., 2016).

As the study model exhibited sufficient reliability and validity, the structural model was subsequently analysed to test the hypotheses. 


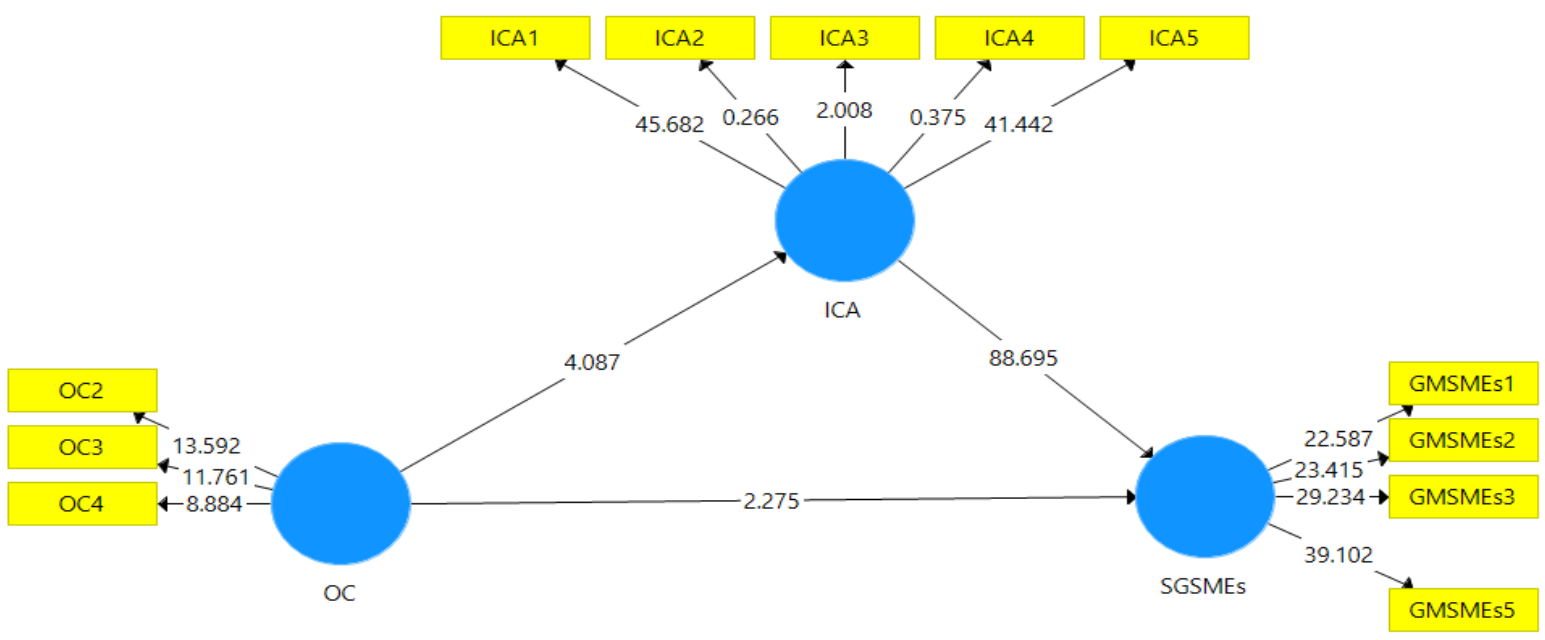

Figure 2 Measurement Model (Factor Loadings)

Table 4 Reliability and Convergent Validity Analysis

\begin{tabular}{|c|c|c|c|c|c|}
\hline Constructs & Items & Loadings & $\begin{array}{l}\text { Cronbach's } \\
\text { Alpha }\end{array}$ & $\begin{array}{l}\text { Composite } \\
\text { Reliability } \\
\text { (CR) }\end{array}$ & $\begin{array}{c}\text { Average } \\
\text { Variance } \\
\text { Extracted } \\
\text { (AVE) }\end{array}$ \\
\hline \multirow[t]{5}{*}{$\begin{array}{l}\text { Organisational } \\
\text { Culture }\end{array}$} & $\mathrm{OC} 1$ & .701 & .753 & .832 & .766 \\
\hline & $\mathrm{OC} 2$ & .744 & & & \\
\hline & OC3 & .767 & & & \\
\hline & $\mathrm{OC} 4$ & .786 & & & \\
\hline & OC5 & .721 & & & \\
\hline \multirow{5}{*}{$\begin{array}{l}\text { Innovation } \\
\text { Competitive } \\
\text { Advantage }\end{array}$} & ICA1 & 758 & 796 & 844 & 747 \\
\hline & ICA2 & .738 & & & \\
\hline & ICA3 & .752 & & & \\
\hline & ICA4 & . 770 & & & \\
\hline & ICA5 & . 768 & & & \\
\hline \multirow{5}{*}{$\begin{array}{l}\text { Sustainable Growth } \\
\text { of SMEs }\end{array}$} & SGSMEs1 & .796 & .862 & .899 & .641 \\
\hline & SGSMEs2 & .801 & & & \\
\hline & SGSMEs3 & .812 & & & \\
\hline & SGSMEs14 & .778 & & & \\
\hline & SGSMEs5 & .814 & & & \\
\hline
\end{tabular}


Table 5 Discriminant Validity (Heterotrait-Monotrait Ratio)

\begin{tabular}{lcll}
\hline & $\begin{array}{c}\text { Innovation } \\
\text { competitive } \\
\text { advantage }\end{array}$ & $\begin{array}{l}\text { Organisational } \\
\text { culture }\end{array}$ & $\begin{array}{c}\text { Sustainable } \\
\text { growth of SMEs }\end{array}$ \\
\hline $\begin{array}{l}\text { Innovation competitive } \\
\text { advantage }\end{array}$ & & & \\
$\begin{array}{l}\text { Organisational Culture } \\
\text { Sustainable Growth of }\end{array}$ & 0.327 & & \\
SMEs & 0.843 & 0.300 \\
\hline
\end{tabular}

Table 6 Variance Inflation Factor (VIF)

\begin{tabular}{lc}
\hline Item & VIF \\
\hline & \\
SGSMEs1 & 1.912 \\
SGSMEs2 & 2.106 \\
SGSMEs3 & 1.762 \\
SGSMEs4 & 2.031 \\
SGSMEs5 & 1.803 \\
OC1 & 1.427 \\
OC2 & 1.220 \\
OC3 & 1.297 \\
OC4 & 1.327 \\
OC5 & 1.437 \\
ICA1 & 1.332 \\
ICA2 & 1.497 \\
ICA3 & 1.391 \\
ICA4 & 1.354 \\
ICA5 & 1.356 \\
\hline
\end{tabular}

\section{Structure Equation Modelling}

Table 7 provided the results for the analysis of the path coefficient for direct hypotheses H1, H2 and $\mathrm{H} 3$. It was revealed that organisational culture has a positive and significant effect on the sustainable growth of SMEs and innovation competitive advantage $(\beta$ value $=0.278, \mathrm{P}$ value $=0.000 ; \beta$ value $=$ 0.248 , $\mathrm{P}$ value $=0.000$ ). Similarly, innovation competitive advantage has a positive and significant effect on the sustainable growth of SMEs with a $\beta$ value $=0.933$ and $P$ value $=0.000$. Accordingly, the three direct hypotheses were all supported.

Table 7 Path Coefficient Analysis Outcomes

\begin{tabular}{|c|c|c|c|c|c|c|}
\hline $\begin{array}{l}\text { Hypothe } \\
\text { ses }\end{array}$ & Relationship & $\begin{array}{l}\text { Std. } \\
\text { Beta }\end{array}$ & SE & $\begin{array}{ll}\text { T } \\
\text { Value }\end{array}$ & $\begin{array}{l}\mathbf{P} \\
\text { Valu } \\
\text { e } \\
\end{array}$ & Decision \\
\hline H1 & Organisational Culture $\rightarrow$ Sustainable Growth of SMEs & 0.278 & 0.057 & 4.755 & 0.000 & $\begin{array}{l}\text { Supporte } \\
\text { d }\end{array}$ \\
\hline $\mathrm{H} 2$ & $\begin{array}{l}\text { Organisational Culture } \rightarrow \text { Innovation } \text { Competitive } \\
\text { Advantage }\end{array}$ & 0.248 & 0.059 & 4.087 & 0.000 & $\begin{array}{l}\text { Supporte } \\
\text { d }\end{array}$ \\
\hline $\mathrm{H} 3$ & $\begin{array}{l}\text { Innovation Competitive Advantage } \rightarrow \text { Sustainable Growth of } \\
\text { SMEs }\end{array}$ & 0.933 & 0.011 & 88.695 & 0.000 & $\begin{array}{l}\text { Supporte } \\
\text { d }\end{array}$ \\
\hline
\end{tabular}




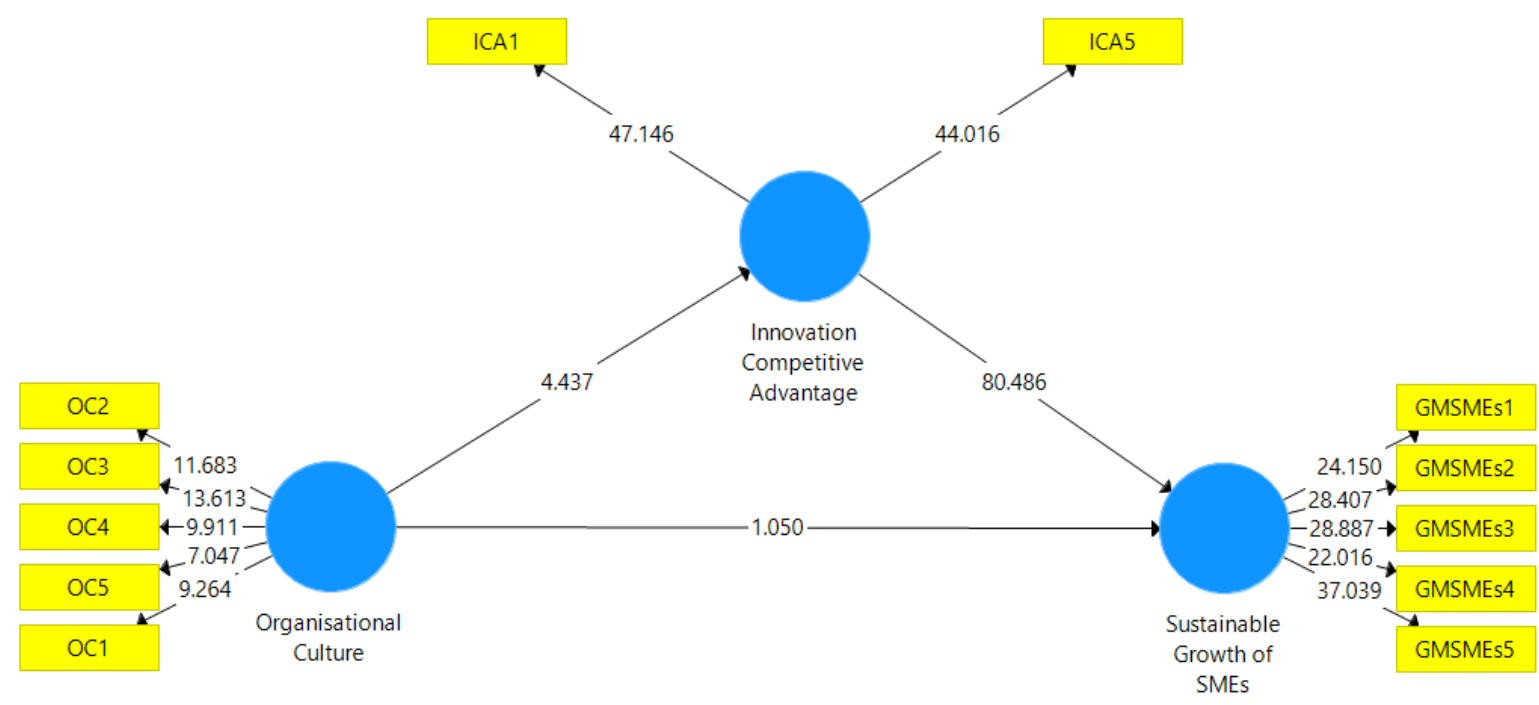

Figure 3: Path Model (Coefficients and P-values)

Table 8 Indirect Effect/Mediation

\begin{tabular}{clccccccc}
\hline Hypothesis & Relationship & $\begin{array}{c}\text { Std. } \\
\text { Beta }\end{array}$ & SE & $\begin{array}{c}\text { T- } \\
\text { Value }\end{array}$ & $\begin{array}{c}\text { P } \\
\text { Value } \\
\text { s }\end{array}$ & $\begin{array}{c}\mathbf{2 . 5 \%} \\
\text { LCL }\end{array}$ & $\begin{array}{c}\mathbf{9 7 . 5} \\
\text { \% } \\
\text { UCL }\end{array}$ & Decision \\
\hline \multirow{2}{*}{ H4 } & $\begin{array}{l}\text { Organisational culture } \rightarrow \\
\text { Innovation Competitive } \\
\text { Advantage } \rightarrow \text { Sustainable } \\
\text { Growth of SMEs }\end{array}$ & 0.246 & 0.052 & 4.463 & 0.000 & & & Support \\
\hline
\end{tabular}

The mediating effect (indirect) of the innovation competitive advantage was determined through the bootstrapping process in PLS-SEM using SmartPLS, in the connection between independent variables (organizational culture) and dependent variable (sustainable growth of SMEs). Bootstrapping technique can be helpful when investigating an indirect effects in relationship (Preacher, \& Hayes, 2008). Bootstrapping can be useful when obtaining ridable results and calculating confidence intervals (CIs) in an indirect relationship (Baron, \& Kenny, 1986; Carrión et al., 2017). The study used 5000 subsample bootstrapping in bias-corrected confidence interval at $95 \%$, which revealed that results in Table 8 as bootstrapped was a powerful tool used for testing the indirect effect (Hayes, 2009; Williams, \& MacKinnon, 2008; Chin et al., 2003).

Findings from the indirect relationship has supported that innovation competitive advantage has a full mediation effect on the relationship between organisational culture and sustainable growths of SMEs with a $\beta$ value 0.246 and P value 0.000 . Therefore, since the $p$-value was less than 0.05 and lower control limit (LCL) and upper control limit (UCL) are out of '0' (zero) value (Sarstedt et al., 2020; Iqbal et al., 2020), the indirect effect of innovation competitive advantage was significant.

\section{Coefficient of Determinant $R^{2}$}

Table 9 R Square

\begin{tabular}{ccc}
\hline & R Square & R Square Adjusted \\
\hline SGSMEs & 0.853 & 0.852 \\
ICA & 0.061 & 0.057 \\
\hline
\end{tabular}

Note: SGSMEs = Sustainable Growth of Small and Enterprises, ICA = Innovation

Competitive Advantage. 
Table 9 indicates that $85.3 \%$ of sustainable growth of SMEs is explained by the predictors, and $6.1 \%$ of innovation competitive advantage is explained by the predictors.

\section{Effect Size Determination $\left(\mathbf{f}^{2}\right)$}

Table 10 F Square

\begin{tabular}{lccccc}
\hline & ICA & OC & SGSMEs & $\begin{array}{c}\text { Effect Size on } \\
\text { SGSMEs }\end{array}$ & $\begin{array}{c}\text { Effect Size on } \\
\text { ICA }\end{array}$ \\
\hline ICA & - & - & 5.352 & Large & - \\
OC & 0.065 & - & 0.007 & No Effect & Small \\
SGSMEs & - & - & - & - & -
\end{tabular}

Note: Organisation Culture (OC), ICA= Innovation Competitive Advantage, Sustainable Growth of Small and Medium Enterprises (SGSMEs).

It can be seen that innovation competitive advantage (ICA) has a large effect on sustainable growth of small and medium enterprises (SGSMEs), whereas organisational culture (OC) has a small effect on ICA and no effect on SGSMEs. Chin, Marcolin and Newsted (2003) advised that the low effect size does not reflect the construct's insignificance, but may be relevant in specific situations. For instance, if the beta coefficient result is eloquent then applying this approach would be advisable (Chin, et al., 2003). Notwithstanding, low effect size does not mean that the variables are not significant to the model.

\section{Predictive Relevance $\left(Q^{2}\right)$}

Table 11 Predictive Relevance $\left(Q^{2}\right)$

\begin{tabular}{cccc}
\hline & SSO & SSE & $\mathbf{Q}^{\mathbf{2}}$ (=1-SSE/SSO) \\
\hline ICA & 1235.000 & 1216.000 & 0.015 \\
OC & 1235.000 & 1235.646 & \\
SGSMEs & 1235.000 & 600.214 & 0.514 \\
\hline
\end{tabular}

The predictive relevance $\left(Q^{2}\right)$ results of the endogenous latent variables in this study are tabulated in Table above. The latent variables $\left(Q^{2}\right)$ in the PLS path model is acquired through the blindfolding procedure. According to (Hair et al., 2019) predictive relevance of 0.02 shows small relevance, that of 0.15 shows medium relevance and that of 0.35 shows large relevance for the specific endogenous constructs.

\section{Discussions}

This study has provided valuable insights on organisational culture and sustainable growth of SMEs in Nigeria. The research has contributed to the existing literature by examining effect of organisational culture on the sustainable growth of SMEs, as well as the mediating role of innovation competitive advantage on organisational culture and sustainable growth of SMEs. The findings has practical implications. The results demonstrate the importance of organisational culture for sustainable growth of SMEs in electrical products sector. Particularly, it revealed that an organisational culture has a direct effect on sustainable growth of SMEs. This findings was consistent with the view of (Schmitt, 2016; Yosuff, 2018). Also, the study confirmed that organisational culture has a direct effect on innovation competitive advantage. Furthermore, innovation competitive advantage has a direct positive relationship with sustainable growth of SMEs. In addition, innovation competitive advantage has fully mediated the effect between organisational culture and sustainable growth of SMEs. This findings was consistent with the research conducted in other settings by (Sheng et al., 2013). In other words, this study contributes significantly in the strategic management research by investigating the inconsistencies asserted regarding the effect of organisational culture on the sustainable growth of SMEs, and filling the lack of empirical literary research on the mediating role of innovation competitive advantage on the effect of organisational culture and sustainable growth of SMEs which is novel and provide new insight to this study (Schmitt, 2018; Nimfa et al., 2020). 
This study further confirms and strengthens the practical view that organisational culture and innovation competitive advantage are essential for an organisation to attain high sustainable growth in an enterprise. The empirical evidence of this research supports the organisational culture and innovation competitive advantage as great pillars necessary for the sustainable growth of SMEs continuity in the present dynamic business environment. In addition, focusing on satisfying the customer needs and responding innovative organisational culture assist the SMEs achieve sustainable growth for sound industrialisation in the economy. This research further inferred that owners or managers of small and medium enterprises should be key to a strategic organisation culture that would enhance the sustainable growth of business through innovation competitive advantage to boost value creation practically.

\section{Conclusion}

This study has confirmed that organisational culture have positive and significant effect on sustainable growth of SMEs and innovation competitive advantage. Also, innovation competitive advantage has a positive and significant effect on sustainable growth of SMEs. Furthermore, organisational culture was revealed to have an indirect effects on sustainable growth of manufacturing SMEs through the mediation of innovation competitive advantage. This study had found a positive and significant effect between organisational culture, sustainable growth of SMEs and innovation competitive advantage. Therefore, it has been confirmed that organisational culture was a viable strategic mechanism which can be implemented by owners or SME managers enhance sustainable growth of the SMEs. Moreover, when the manufacturing SMEs consider the application of innovation competitive advantage as an organisational ability, it will achieve higher and direct or indirect sustainable growth in business operations. . Finally, this current research contributes practically by reinforcing a robust and flexible system by fostering an innovative organisational culture that would drive the sustainable growth of SMEs for industrialisation in line with the Sustainable Development Goals Agenda of the United Nations.

\section{Limitations and Future Directions}

The study is the cross-sectional nature of survey, which does not permit for evaluation of causes and effects that change with time. The analysis also centred on the self-survey of electrical products SME managers to measure organisational culture and sustainable growth of SMEs, which will unlikely convey the enterprises real operations. Additionally, this research only studied one mediating variable, innovation competitive advantage, based on the knowledge of this research, innovation competitive advantage as a mediator variable is lacking empirical literature. Future researchers can explore new research in this variable (innovation competitive advantage) to generate empiric literary knowledge. Ultimately, this research model was employ in the context of Nigeria, likewise, other emerging countries can test in their own context to see whether it can work for them. Future research can also replicate this study in specific areas, such as service and multinationals companies to see the role of ICA on the sustainable growth of the firm in a universal situation.

\section{References}

Abdul-Halim, H., Ahmad, H. N., Geare, A., \& Thurasamy, R. (2018). Innovation culture in SMEs: The importance of organizational culture, organizational learning and market orientation. Entrepreneurship Research Journal, 9(3), 1-14, doi.org/10.1515/erj-2017-0014.

Abdul-Rashid, S. H., Sakundarini, N., Ghazilla, R. A. R., \& Thurasamy, R. (2017). The impact of sustainable manufacturing practices on sustainability performance. International Journal of Operations \& Production Management, 37, 182-204, doi.org/10.1108/IJOPM-04-20150223.

Adebayo, A. (2011). Organizational culture and performance: the role of management accounting system. Journal of Applied Accounting Research, 12(1), 74-89, doi.org/10.1108/09675421111130621. 
Ahmad, K. Z., Veerapandian, K., \& Ghee, W. (2011). Person - environment fit: the missing link in the organizational culture - commitment relationship. International Journal of Business and Management, 6(11), 11-20, doi:10.5539/ijbm.v6n11p11.

Akinson, O. A. (2018). Effect of infrastructural facilities on SMEs growth in Nigeria. International Journal of Innovation Research and Development, 7(6), 196-203, doi:10.24940/ijird/2018/v7/i6/JUN18117.

Al Badi, K. (2019). Implementation of marketing concept and organizational culture in SMEs in Al Buraimi-Oman. Benchmarking: An International Journal, 26(7), 2401-2414, doi.org/10.1108/BIJ-05-2018-0136.

Al-Ansari, Y. D. Y. (2014). Innovation practices as a path to business growth performance: a study of small and medium sized firms in the emerging UAE market PhD Theses. Southern Cross University. Southern Cross Business School, Gold Coast Campus, Queensland, Australia, available at: https://epubs.scu.edu.au/cgi/viewcontent.cgi?article $=1363 \&$ context=theses, (accessed May 7, 2020).

Angelmar, R. (1990). Product innovation: A tool for competitive advantage. European Journal of Operational Research, 47(2), 182-189, doi.org/10.1016/0377-2217(90)90277-I.

Anwar, M. (2018). Business model innovation and SMEs performance - does competitive advantage mediate? International Journal of Innovation Management. 22(07), 1850057-1-185005731, doi.org/10.1142/S1363919618500573.

Anwar, M., Khan, S. Z., \& Khan, N. U. (2018). Intellectual capital, entrepreneurial strategy and new ventures performance: Mediating role of competitive advantage. Business and Economic Review, 10(1), 63-93.

Anwar, M., Rehman, A.U., \& Shah, S.Z.A. (2018). Networking and new venture's performance: mediating role of competitive advantage. International Journal of Emerging Markets, 13(5), 998-1025, doi.org/10.1108/IJoEM-07-2017-0263.

Arora, L., Kumar, S., \& Thapar, M. L. (2018). The anatomy of sustainable growth rate of Indian manufacturing firms. Global Business Review 19(4) 1050-1071, doi.org/10.1177/0972150918773002.

Asare, A. (2014). Challenges affecting SME's growth in Ghana. OIDA International Journal of Sustainable Development, 7(06), 23-28.

Babcock, G. C. (1970). The concept of sustainable growth. Financial Analysts Journal, 26(3), 108114, doi.org/10.2469/faj.v26.n3.108.

Barney, J. B. (1986). Organizational culture: can it be a source of sustained competitive advantage?. Academy of Management Review, 11(3), 656-665, doi.org/10.5465/amr.1986.4306261.

Baron, R. M., \& Kenny, D. A. (1986). The moderator-mediator variable distinction in social psychological research: Conceptual, strategic, and statistical considerations. Journal of personality and social psychology, 51(6), 1173- 1182.

Bell, R. (2019). Dealing with common method variance and bias in business and management research: The impact of basketball coaches' cross-cultural communication competence. SAGE Publications Ltd, doi.org/10.4135/9781526467119.

Brannick, M. T., Chan, D., Conway, J. M., Lance, C. E., \& Spector, P. E. (2010). What is method variance and how can we cope with it? A panel discussion. Organizational Research Methods, 13(3), 407-420, doi.org/10.1177/1094428109360993.

Buowari, E. P. (2015). Factors required for small business sustainability in Nigeria. Walden dissertations and doctoral studies, Walden University, 1-180.

Cameron, K. S., \& Quinn, R. E. (2006). Diagnosing and changing organizational culture: Based on the competing values framework (Rev. ed.). San Francisco, CA: Jossey-Bass.

Carrión G. C., Nitzl C., \& Roldán J. L. (2017). Mediation analyses in partial least squares structural equation modelling: guidelines and empirical examples. In: Latan H., Noonan R. (eds) Partial Least Squares Path Modelling. Springer, Cham. Journal of Management Control 28(2), 137156, doi.org/10.1007/978-3-319-64069-3_8. 
Ćelić, Đ., Ćosić, I., Uzelac, Z., \& Petrov, V. (2019). The relationship between organizational culture and performance of SME's: empirical study from a developing country. Tehnički vjesnik, 26(6), 1620-1627, doi.org/10.17559/TV-20180801135606.

Chen, Y. S., Lin, M. J. J., \& Chang, C. H. (2009).The positive effects of relationship learning and absorptive capacity on innovation performance and competitive advantage in industrial markets. Industrial marketing management, 38(2), 152-158, doi.org/10.1016/j.indmarman.2008.12.003.

Chin, W. W., Marcolin, B. L., \& Newsted, P. R. (2003). A partial least squares latent variable modeling approach for measuring interaction effects: Results from a Monte Carlo simulation study and an electronic-mail emotion/adoption study. Information Systems Research, 14(2), 189-217.

Cohen, J. (1992). A power primer. Psychological Bulletin, 112, 155-159.

Conto, S. M. D., Júnior, A., Valle, J. A., \& Vaccaro, G. L. R. (2016). Innovation as a competitive advantage issue: A cooperative study on an organic juice and wine producer. Gestão \& Produção, 23(2), 397-407, doi.org/10.1590/0104-530x1677-14.

Conway, J. M., \& Lance, C. E. (2010). What reviewers should expect from authors regarding common method bias in organizational research. Journal of Business and Psychology, 25(3), 325-334, doi.org/10.1007/s10869-010-9181-6.

Daft, R. L. (2005). The leadership experience, 3rd ed., Thomson-South Western.

Diabate, A., Allate, M. B., Wei, D., \& Yu, L. (2019a). Do firm and entrepreneur characteristics play a role in SMEs' sustainable growth in a middle-income economy like Côte d'Ivoire? Sustainability, 11(6), 1557, doi.org/10.3390/su11061557.

Diabate, A., Sibiri, H., Wang, L., \& Yu, L. (2019b). Assessing SMEs' sustainable growth through entrepreneurs' ability and entrepreneurial orientation: an insight into SMEs in Côte d'Ivoire. Sustainability, 11(24), 7149, doi.org/10.3390/su11247149.

Dirsehan, T. (2015). Building innovative competitive advantage in the minds of customers. Adoption of innovation, Springer International Publishing Switzerland. A. Brem, E. Viardot (eds.), Adoption of Innovation, 75-93, doi.10.1007/978-3-319-14523-5_6.

Distanont, A., \& Khongmalai, O. (2018). The role of innovation in creating a competitive advantage. Kasetsart Journal of Social Sciences, 41, 15-21, doi:10.1016/j.kjss.2018.07.009.

Doty, D. H., \& Astakhova, M. (2020). Common Method Variance in International Business Research: $\quad$ A Commentary. In Research Methods in International Business (pp. 399408). Palgrave Macmillan, Cham.

Dzomonda, O., \& Fatoki, O. (2019). Evaluating the impact of organisational culture on the entrepreneurial orientation of small and medium enterprises in South Africa. Bangladesh eJournal of Sociology, 16(1), 82-220.

Eggers, F., Kraus, S., Hughes, M., Laraway, S., \& Snycerski, S. (2013b). Implications of customer and entrepreneurial orientations for SME growth. Management Decision, 51(3), 524-546, doi.org/10.1108/00251741311309643.

Eggers, F., O’Dwyer, M., Kraus, S., Vallaster, C., \& Güldenberg, S. (2013a). The impact of brand authenticity on brand trust and SME growth: A CEO perspective. Journal of World Business, 48(3), 340-348, doi.org/10.1016/j.jwb.2012.07.018.

Ezie, O., \& Nimfa, T. D. (2016). Entrepreneurial orientation and business performance of SMEs in Nigeria: A study of selected SMEs in North Central Nigeria. International Journal of Management Science Research, 1(1), 249-263.

Globocnik, D., Rauter, R., \& Baumgartner, R. J. (2020). Synergy or conflict? The relationships among organisational culture, sustainability-related innovation performance, and economic innovation performance. International Journal of Innovation Management, 24(01), 2050004, doi.org/10.1142/S1363919620500048.

Goffee, R. \& Jones, G. (1998). The character of a corporation: how your company's culture can make or break your business. Harper Business, London. 
Goksoy, A., Vayvay, O., \& Ergeneli, N. (2013). Gaining competitive advantage through innovation strategies: an application in warehouse management processes. American Journal of Business and Management, 2(4), 304-321, doi.org/10.11634/216796061706463.

Gorondutse, A. H., \& Hilman, H. (2015). Does organizational culture on the relationship moderate the relationship between trust of BSR and performance of BSR on performance of small scale industries: partial least square (PLS). Advances in Global Business Research, 12(1), 795-809.

Gorondutse, A. H., \& Hilman, H. (2019). Does organizational culture matter in the relationship between trust and SMEs performance? Management Decision. 57(7), 1638-1658, doi.org/10.1108/MD-05-2018-0557.

Gross-Gołacka, E., Kusterka-Jefmańska, M., \& Jefmański, B. (2020). Can elements of intellectual capital improve business sustainability?-the perspective of managers of SMEs in Poland. Sustainability, 12(4), 1545, doi.org/10.3390/su12041545.

Hair Jr, J. F., Sarstedt, M., Hopkins, L., \& Kuppelwieser, V. G. (2014). Partial least squares structural equation modeling (PLS-SEM). European business review. 26(2), 106-121, doi.org/10.1108/EBR-10-2013-0128.

Hair Jr, J. F., Sarstedt, M., Ringle, C. M., \& Gudergan, S. P. (2018). Advanced issues in partial least squares structural equation modeling. Sage publications. 1-247.

Hair, J. F., Risher, J. J., Sarstedt, M., \& Ringle, C. M. (2019). When to use and how to report the results of PLS-SEM. European Business Review, doi.org/10.1108/EBR-11-2018-0203.

Hair, J., Bush, R., \& Ortinau, D. (2006). Marketing research within a changing environment. Revised international edition. McGraw-Hill, New York, USA, 589, 566.

Hami, N., Muhamad, M. R., \& Ebrahim, Z. (2016). The impact of sustainable manufacturing practices on sustainability. Jurnal Teknologi, 78(1), 139-152. jurnalteknologi.utm.my.

Hayes, A. F. (2009). Beyond Baron and Kenny: Statistical mediation analysis in the new millennium. Communication monographs, 76(4), 408-420, doi.org/10.1080/03637750903310360.

Hofstede, G. (1990). Cultures and organizations. Software if the mind. NY.

Hung, R., Yang, B., \& Lien, B. (2010). Dynamic capability: impact of process alignment and organizational learning culture on performance. Journal of World Business, 45(3), 285-294, doi.org/10.1016/j.jwb.2009.09.003.

Hynes, N. (2009). Corporate culture, strategic orientation, and business performance: New approaches to modelling complex relationships. Technological Forecasting and Social Change, 76(5), 644-651, doi.org/10.1016/j.techfore.2008.08.014.

Igartua, I. J., Garrigós, A. J., \& Hervas-Oliver, L. J. (2010). How innovation management techniques support an open innovation strategy how innovation management techniques support an open innovation strategy. Research-Technology Management, 53(3) 41-52.

Iqbal, Q., Ahmad, N. H., Nasim, A., \& Khan, S. A. R. (2020). A moderated-mediation analysis of psychological empowerment: Sustainable leadership and sustainable performance. Journal of Cleaner Production, 262, 121429, doi.org/10.1016/j.jclepro.2020.121429.

Khedhaouria, A., Nakara, W. A., Gharbi, S., \& Bahri, C. (2020). The relationship between organizational culture and small-firm performance: Entrepreneurial orientation as mediator. European Management Review. doi:10.1111/emre.12383.

Kock, N., \& Lynn, G.S. (2012). Lateral collinearity and misleading results in variance-based SEM: an illustration and recommendations. Journal of the Association for Information Systems, 13(7), 546-580, available at: https://ssrn.com/abstract=2152644 (accessed 09, 2021).

Kraus, P., Stokes, P., Cooper, S. C., Liu, Y., Moore, N., Britzelmaier, B., \& Tarba, S. (2020). Cultural antecedents of sustainability and regional economic development-A study of SME 'Mittelstand' firms in Baden-Württemberg (Germany). Entrepreneurship \& Regional Development, 1-25, doi.org/10.1080/08985626.2020.1713223.

Mekwunye, U. (2018). Small and medium scale enterprises In Nigeria, An overview of initial setup, available at: https://www.mondaq.com/nigeria/corporatecommercial-law/757432/small- 
and- medium-scale-enterprises-in-nigeria-an-overview-of-initial-set-up (accessed April 2, 2020).

Mohammed, H.; Nimfa, T. D.; Maimako, L. N. \& Idris, I. R. (2020). Effect of digital manufacturing and consumer behaviour on firm sustainability in Malaysia. e-Book of the 8th International Seminar of Entrepreneurship and Business (ISEB 2020), 70-96, available at: https://fkpportal.umk.edu.my/web/chapterinbook/paper?purl=current-issues-entrepreneurshipbusiness-2020 (accessed January 5, 2021).

National Bureau of Statistics (NBS) \& Small \& Medium Enterprises Development Agency Nigeria (SMEDAN) (NBS/SMEDAN, 2017). National survey of micro small \& medium enterprises (MSMES) 2017, 1-148.

Nimfa, T. D., \& Gajere. C. M (2017). Small scale enterprises innovation and youths empowerment for local economic growth in Kanam L.G.A of Plateau State-Nigeria. IOSR Journal of Business and Management (IOSR-JBM), 19(10), 1-12, doi.10.9790/487X-1910030112, available at: www.iosrjournals.org (accessed January, 20, 2021).

Nimfa, T. D., Latiff, A. S. A., \& Wahab, S. A. (2020). Instrument for testing innovation on the sustainable growth of manufacturing SMEs in Nigeria: A Pilot Study. Journal of Economic and Management Sciences, 3(2), 57-70, doi.org/10.30560/jems.v3n2p57.

Nimfa, T. D., Yunus, M R. B. M., Latiff, A, S. A., Wahab, A. S., \& Mahmood, R. (2019). Sustainable innovation and creativity for value creation: a study of hospitality enterprises in Jos Metropolis, Nigeria. European Journal of Business and Management, 11(26), 35-48, doi: 10.7176/ejbm/11-26-04.

Nor-Aishah, H., Ahmad, N. H., \& Thurasamy, R. (2020). Entrepreneurial leadership and sustainable performance of manufacturing SMEs in Malaysia: The contingent role of entrepreneurial bricolage. Sustainability, 12(8), 3100, doi.org/10.3390/su12083100.

Paswan, A.K., \& Wittmann, C.M. (2009).Knowledge management and franchise systems. Industrial Marketing Management, 38(2), 173-180, doi.org/10.1016/j.indmarman.2008.12.005.

Peteraf, M. (1993). The cornerstones of competitive advantage: a resource-based view. Strategic Management Journal, 14(3), 179-191, doi.org/10.1002/smj.4250140303.

Podsakoff, P. M., \& Organ, D. W. (1986). Self-reports in organizational research: Problems and prospects. Journal of management, 12(4), 531-544, doi.org/10.1177/014920638601200408.

Podsakoff, P. M., MacKenzie, S. B., Lee, J. Y., \& Podsakoff, N. P. (2003). Common method biases in behavioral research: a critical review of the literature and recommended remedies. Journal of Applied Psychology, 88, 879-903, doi.org/10.1037/0021-9010.88.5.879.

Porter, M. E. (1990). The Competitive Advantage of Nations. Free Press, New York.

Preacher, K. J., \& Hayes, A. F. (2008). Asymptotic and resampling strategies for assessing and comparing indirect effects in multiple mediator models. Behaviour research methods, 40(3), 879-891, doi.org/10.3758/BRM.40.3.879.

Rua, O., França, A., \& Fernández Ortiz, R. (2018). Key drivers of SMEs export performance: the mediating effect of competitive advantage. Journal of Knowledge Management, 22(2), 257279, doi.org/10.1108/JKM-07-2017-0267.

Saleh, A. S., \& Ndubisi, N. O. (2006). SME development in Malaysia: Domestic and global challenges, working paper 06-03, Department of Economics, University of Wollongong, 127, available at: https://ro.uow.edu.au/commwkpapers/139/ (accessed June 16, 2020).

Santti, U., Eskelinen, T., Rajahonka, M., Villman, K., \& Happonen, A. (2017). Effects of business model development projects on organizational culture: a multiple case study of SMEs. Technology Innovation Management Review, 7(8), 15-26, doi.org/10.22215/timreview/1096.

Sarstedt, M., Hair Jr, J. F., Nitzl, C., Ringle, C. M., \& Howard, M. C. (2020). Beyond a tandem analysis of SEM and PROCESS: Use of PLS-SEM for mediation analyses!. International Journal of Market Research, 62(3), 288-299, doi.org/10.1177/1470785320915686.

Schein, E. H. (1990). Organizational culture. American Psychologist, 45(2), 109-119, doi.org/10.1037/0003-066X.45.2.109. 
Schmitt, U. (2016, December). Strengthening SMEs impact and sustainability with the support of personal knowledge management systems and concepts. In 15th International Entrepreneurship Forum (IEF) Conference Proceedings (Vol. 2, pp. 14-16).

Schmitt, U. (2018). Supporting the sustainable growth of SMEs with content-and collaboration based personal knowledge management systems. Journal of Entrepreneurship and Innovation in Emerging Economies, 4(1), 1-21, doi: 10.1177/2393957517739773.

Sekaran, U., \& Bougie, R. (2016). Research methods for business: a skill-building approach, 7th ed.; John Wiley \& Sons: Chichester, UK.

Sheng, M. L., Chang, S. Y., Teo, T., \& Lin, Y. F. (2013). Knowledge barriers, knowledge transfer, and innovation competitive advantage in healthcare settings. Management Decision. 51(3), 461-478, doi.org/10.1108/00251741311309607.

Spence, L. J. (2016). Small business social responsibility: expanding core CSR Theory.” Business and Society 55 (1): 23-55, doi: 10.1177/0007650314523256.

Srisathan, W.A., Ketkaew, C., \& Naruetharadhol, P. (2020). The intervention of organizational sustainability in the effect of organizational culture on open innovation performance: A case of Thai and Chinese SMEs. Cogent business \& management, 7(1), 1717408, doi.org/10.1080/23311975.2020.1717408.

Tang, T. L. P., Kim, J. K., \& O’Donald, D. A. (2000). Perceptions of Japanese organizational culture employees in non-unionized Japanese-owned and unionized US-owned automobile plants. Journal of Managerial Psychology, 15(6), 535-559.

Taylor, J. (2014). Organizational culture and the paradox of performance management. Public Performance \& Management Review, 38(1), 7-22, doi: 10.2753/pmr1530-9576380101.

Teece, D. J., Pisano,G., \& Shuen, A. (1997). Dynamic capabilities and strategic management. Strategic Management Journal, 18(7), 509-533

Virameteekul, V. (2011). Message from ministry of science and technology. Retrieved at: www.thailandinnovativecompanies.com/ttd_bizenterprise/Indprof/TTIC/TTIC_2011_IPO2 pdf (Accessed July 5, 2020).

Voorhees, C. M., Brady, M. K., Calantone, R., \& Ramirez, E. (2016). Discriminant validity testing in marketing: an analysis, causes for concern, and proposed remedies. Journal of the Academy of Marketing Science, 44(1), 119-134, doi.org/10.1007/s11747-015-0455-4.

Wallach, E. (1983), "Individuals and organizations: the cultural match", Training \& Development Journal, 37(2), 29-36.

Whalen, E. A., \& Han, J. (2017). The innovative competitive advantage: A case study of two pioneering companies. International CHRIE.

Wickert, C., Scherer, A. G., \& Spence, J. L. (2016). Walking and talking corporate social responsibility: Implications of firm size and organizational cost. Journal of Management Studies, 53(7), 1169-1196, doi:10.1111/joms.2016.53.

Williams, J., \& MacKinnon, D. P. (2008). Resampling and distribution of the product methods for testing indirect effects in complex models. Structural Equation Modeling: a

Multidisciplinary Journal, 15(1), 23-51, doi.org/10.1080/10705510701758166.

Yoo, W. J., Choo, H. H., \& Lee, S. J. (2018). A Study on the sustainable growth of SMEs: The mediating role of organizational metacognition. Sustainability, 10(8), 2829, doi.org/10.3390/su10082829.

Yosuff, T. (2018). Relationships between growth intention, organisational culture, dynamic capabilities, networking capabilities and SMEs sustainable growth. Unpublished $\mathrm{PhD}$. Thesis Universiti Malaysia Kelantan, 1-364.

Yusoff, T., Wahab, A. S., Latiff, A. S. A., Osman,W. I. S., Zawawi, M. F. N., \& Fazal, A. S. (2018). Sustainable growth in SMEs: A review from the Malaysian perspective. Journal of Management and Sustainability, 8(3), 43-54, doi:10.5539/ jms.v8n3p43.

Zhang, H., Wang, Y., \& Song, M. (2020). Does competitive intensity moderate the relationships between sustainable capabilities and sustainable organizational performance in new ventures?. Sustainability, 12(1), 253, doi.org/10.3390/su12010253 